九州大学学術情報リポジトリ

Kyushu University Institutional Repository

\title{
The Production of Bioinsecticide Based From Pong-Pong Fruit Seed Extract by Ultrasonic Waved Extraction Using NADES Solvent
}

Gibranadhi

Department of Chemical Engineering, Faculty of Engineering, University of Indonesia

Sungkar, Meizka

Department of Chemical Engineering, Faculty of Engineering, University of Indonesia

Tania Surya Utami

Department of Chemical Engineering, Faculty of Engineering, University of Indonesia

Arbianti, Rita

Department of Chemical Engineering, Faculty of Engineering, University of Indonesia

他

https://doi.org/10.5109/4055237

出版情報：Evergreen. 7 (2)，pp.303-308，2020-06. 九州大学グリーンテクノロジー研究教育センター バージョン：

権利関係 : 


\title{
The Production of Bioinsecticide Based From Pong-Pong Fruit Seed Extract by Ultrasonic Waved Extraction Using NADES Solvent
}

\author{
Gibranadhi $^{1}$, Meizka Sungkar ${ }^{1}$, Tania Surya Utami ${ }^{1, *}$, Rita Arbianti ${ }^{1}$, \\ Heri Hermansyah ${ }^{1}$
}

\begin{abstract}
${ }^{1}$ Department of Chemical Engineering, Faculty of Engineering, University of Indonesia, Depok 16424, Indonesia
\end{abstract}

*Author to whom correspondence should be addressed:

E-mail: nana@che.ui.ac.id

(Received November 13, 2019; Revised May 2, 2020; accepted May 21, 2020).

\begin{abstract}
Cutworms population is increasing rapidly and may damage crops in Indonesia. Therefore, control of those pests is needed using bioinsecticides obtained from Pong-Pong fruit seed extract. These seeds have an active ingredient from alkaloid and steroid groups that can eliminate the worms. The seeds are prepared by mashing and mixing them with a Natural Deep Eutectic Solvent (NADES) and undergo ultrasonic-assisted extraction (UAE) with different concentration and sonication times to obtain the most optimal one by checking the most lethal extract given to the worms. Tests using Liebermann-Burchard, FTIR and LCMS have identified the components of the extract.
\end{abstract}

Keywords: Cutworms, Pong-Pong seed, NADES, UAE, Libermann-Burchard, FTIR, LCMS

\section{Introduction}

Spodoptera litura or tobacco cutworms are known as one of the pests that attack and eating leaves of the plant until there are nothing left ${ }^{1)}$. Among them are attacks on tobacco plants that result in perforated tobacco leaves that reduces production up to $50 \%^{2}$. Several ways have been done to control the population of Spodoptera litura to not endanger the plants that are ready to harvest such as using chemical insecticides. However, there are negative side effects from insecticide use such as emergence of new pests, accumulation of chemical residues in plants, and pollution of soil by chemicals.

The recommended alternative method is to use bioinsecticides. Bioinsecticides have advantages over chemical insecticides, which are more environmentally friendly, do not cause resistance to pests, and are not harmful to plants ${ }^{3)}$. One type of natural substance that can be used as a raw material for making bioinsecticides is pong-pong fruit (Cerbera odollam). The peel, meat, and fruit seeds contain the main compounds of steroid and alkaloid. Steroids and alkaloids will be extracted from pong-pong fruit seeds because pong-pong fruit seed extract is more potential in killing larvae ${ }^{4}$. A notable steroid present in the fruit seed, Cerberin, are toxic compounds that can cause a decrease in heart rate and also reduces the motoric activity of humans and animals ${ }^{5-6)}$.
Extraction will be carried out with the help of ultrasonic waves using Natural Deep Eutectic Solvents or abbreviated as NADES.

NADES is a mixture of compounds that have a lower melting point than each individual compound, mainly due to the formation of intermolecular hydrogen bonds ${ }^{7}$. NADES is predicted to be able to replace the role of methanol as a solvent because of its polarity and its more environmentally friendly nature ${ }^{8}$. The type of NADES solvent used is a mixture of choline chloride $(\mathrm{ChCl})$ and lactic acid because of its ease of synthesis, availability, and good biodegradability9). This is to improve environmental sustainability and support previous proposed initiatives on the same topic, such as green human resource management and producing pyrolysis oil from palm empty fruit bunches ${ }^{10-11)}$

The bioinsecticide extracted from pong-pong fruit using NADES solvent is more environmentally friendly compared to chemical insecticides and caused almost no harm as long as it is not overused. This trait also adds the potential of this bioinsecticide to be used regularly.

The aim for this research is to collect the extract from pong-pong fruit seeds and to observe the effect of extract concentration and sonication time to the mortality percentage of Spodoptera litura. 


\section{Methodology}

\subsection{Preparation}

The first preparation for this research is to prepare the pong-pong fruit, which is obtained in Tangerang, Indonesia. The fruit obtained is ripe indicated by the reddening of the pong-pong fruit skin and with the fruit falling down from the tree ${ }^{12)}$. Next, the pong-pong fruit will be peeled and cut to obtain the seed inside. The seeds are then washed using water and dried using an oven with temperature of $60^{\circ} \mathrm{C}$ for 3 days. The dried seeds will be crushed and blended forming small powdered pieces. The seed powder is then sieved using a mesh 40 sieve $(0.42$ $\mathrm{mm})$.

After the seed powder is obtained, the NADES solvent which is a mixture of choline chloride and lactic acid will be prepared. Solvent preparation was carried out by dissolving 39,276 g of choline chloride with $21 \mathrm{~mL}$ of lactic acid which had a mole ratio of $1: 1$ with magnetic stirring at $85{ }^{\circ} \mathrm{C}$ for 45 minutes until the mixture is homogeneous which is marked with a clear solution, then the temperature would be reduced to $50{ }^{\circ} \mathrm{C}$ with stirring for 15 minutes to ensure the lactic acid and choline chloride are well-mixed.

Finally, the pong-pong fruit seeds will be extracted. The procedure begins with the preparation of six test tubes with two test tubes filled with $0.140 \mathrm{~g}$ of pong-pong fruit seed powder, two tubes filled with $0.280 \mathrm{~g}$ of pong-pong fruit seed powder, and the remaining two tubes filled with $0.420 \mathrm{~g}$ of pong-pong fruit seed powder. $7 \mathrm{ml}$ of NADES solvent is then inserted to each of the six test tubes. The six test tubes are then put into a glass cup filled with half water and the glass is placed in an ultrasonic indicator. Extraction is carried out with a sonication time of 20 minutes with a frequency of $53 \mathrm{kHz}$ with a temperature of $37{ }^{\circ} \mathrm{C}$. The pong-pong fruit seed extract is obtained in liquid phase with concentrations of $20 \mathrm{mg} / \mathrm{mL}, 40 \mathrm{mg} / \mathrm{mL}$, and $60 \mathrm{mg} / \mathrm{mL}$ for each of the 2 samples. The choice of concentration is based on research proving the most effective in the range in $20-60 \mathrm{mg} / \mathrm{mL}^{13-14}$.

The second extraction is carried out after the most effective concentration from the first batch is obtained. In the second batch, ten samples of pong-pong fruit seed extract is prepared. The four samples will be extracted using the same procedure with NADES solvent, but with different sonication times; two samples at 40 minutes and 2 samples at 60 minutes. The other six will be extracted using distilled water as solvents with the same conditions. The choice of range for the sonication time from the extraction of ultrasonic waves in natural materials is because it is usually carried out in a span of 10-60 minutes as the optimal results are usually present at that time ${ }^{15)}$.

\subsection{Testing}

The first tests, which are Liebermann and FourierTransform Infrared (FTIR) Spectroscopy tests, are conducted to identify if the active ingredient is successfully extracted from the pong-pong fruit seed. The procedure for Liebermann test is started by inserting $2 \mathrm{~mL}$ of the sample to a test tube. Next, $2 \mathrm{~mL}$ of glacial acetic acid is inserted to the test tube. Then, 3 drops of concentrated sulphuric acid is inserted to a test tube. The positive result of this test is the emergence of green color from the mixture ${ }^{16)}$. In the FTIR spectroscopy test, the sample will be analyzed to see the types of groups and bonds present. The result of FTIR test will be the transmittance of light in certain wavenumbers. IR light will be absorbed by certain bonds and groups of the substance present in the extract and the transmittance shows the amount of IR light unabsorbed.

Following these qualitative tests is the efficacy test which is done to observe the effectiveness of the bioinsecticide extract from pong-pong fruit seed. The efficacy test is carried out with bioinsecticide extracts from the three variations of pong-pong fruit seed concentration (20 $\mathrm{mg} / \mathrm{mL}, 40 \mathrm{mg} / \mathrm{mL}$, and $60 \mathrm{mg} / \mathrm{mL}$ ) and NADES solvent as a control. Tests were carried out by putting 4 drops of bioinsecticides from both samples for each concentration and NADES solvent on both surface of the mustard green leaf using a pipette. The leaves are then placed on a plastic container with a tissue mat. Then, ten worms on the 3rd instar phase are placed into each container. Observation of the mortality of worms for the seven samples will be monitored per day for 3 days. After the result of the first efficacy test is obtained, the second batch of extracts is also tested using the same efficacy test. In the end, the most effective extract is tested with LCMS (Liquid Chromatography Mass Spectrometry) test to determine the exact molecules inside the extract.

\section{Results and Discussions}

\subsection{Liebermann-Burchard Test}

The result of the Liebermann test shows that all the mixtures of the samples change color to green. This result indicates that the pong-pong seed fruit extract with the concentration of $20 \mathrm{mg} / \mathrm{mL}, 40 \mathrm{mg} / \mathrm{mL}, 60 \mathrm{mg} / \mathrm{mL}$ all have glycosides, which are also steroids, and the extraction process is successful.

The green color came from the reaction between the acidic reagents and aglycone of glycosides. The aglycone will react with glacial acetic acid and sulfuric acid where protonation of hydroxyl group will occur. Then, oxidative elimination will occur and a $-\mathrm{SO}_{3} \mathrm{H}$ group will form on the part that was left by the hydroxyl group and form sulfonic acid which will give out the green color ${ }^{17-19)}$.

Table 1. Result of Liebermann Test

\begin{tabular}{|c|c|c|c|}
\hline Concentration & $20 \mathrm{mg} / \mathrm{mL}$ & $40 \mathrm{mg} / \mathrm{mL}$ & $60 \mathrm{mg} / \mathrm{mL}$ \\
\hline $\begin{array}{c}\text { Green Color } \\
\text { Presence }\end{array}$ & $\mathrm{V}$ & $\mathrm{V}$ & $\mathrm{V}$ \\
\hline
\end{tabular}




\subsection{FTIR Spectroscopy Test}

The FTIR tests are conducted on 20 and $40 \mathrm{mg} / \mathrm{mL}$ extracts only. The results are as seen on Figure 1.

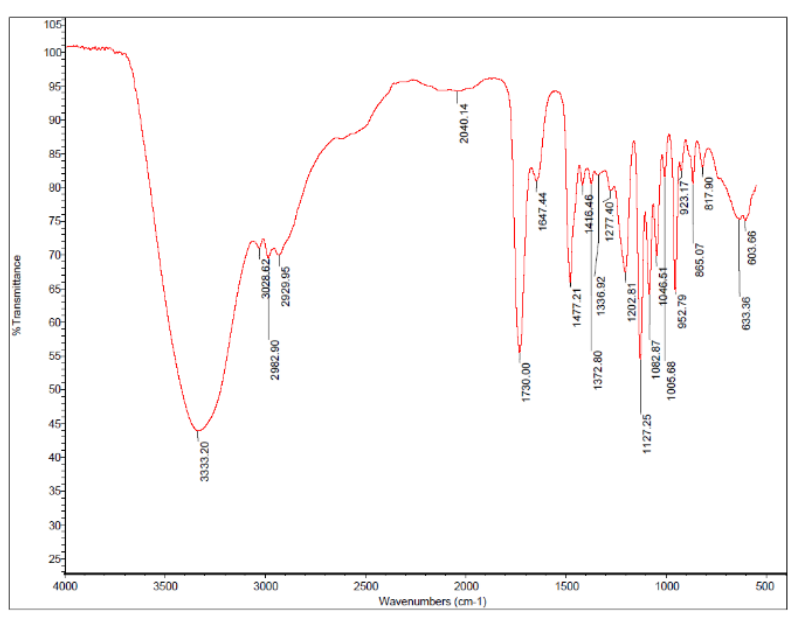

(a)

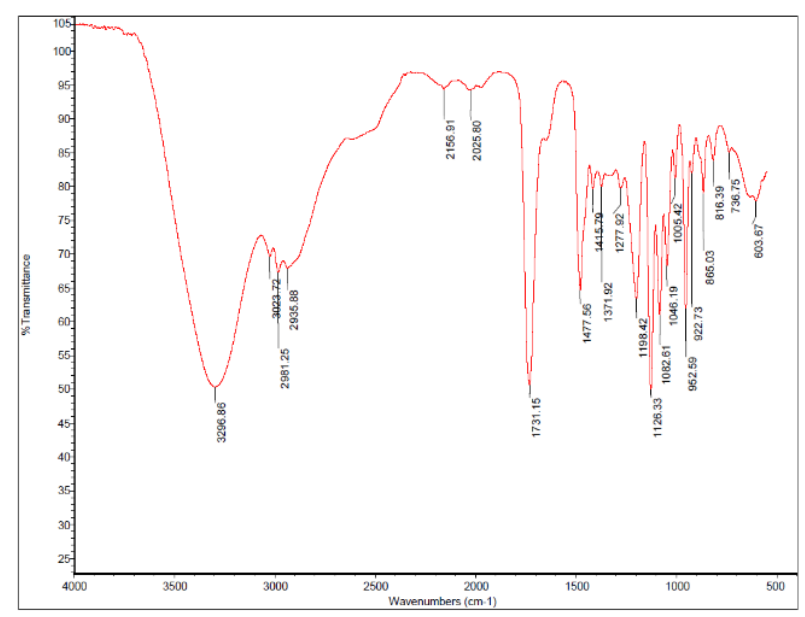

(b)

Figure 1. FTIR Profile of Pong-Pong Fruit Seed Extract of concentration: (a) $20 \mathrm{mg} / \mathrm{mL}$; (b) $40 \mathrm{mg} / \mathrm{mL}$

From the results of FTIR test on pong-pong fruit seed extract obtained, all samples give out the same peak pattern, but with different percentage of transmittance. Transmittance on IR shows the ability of a group or bond to absorb IR rays. The lower the transmittance, the stronger the group or bond in absorbing the light and the higher the absorbance. Absorbance is also known to be proportional to the concentration of the species that absorbs it. So, it can be concluded that all samples have the same composition, but the concentration is different ${ }^{20)}$.

When matched from the table of IR spectra readings, it is found that there were 4 types of significant groups and bonds in the sample: the alcohol group is characterized by a strong and wide peak on wavenumber $3299-3333 \mathrm{~cm}^{-1}$, $\mathrm{CH} \mathrm{sp}^{3}$ hybridization bonds are characterized by a moderate peak on wavenumber $2930-2982 \mathrm{~cm}^{-1}$, CH sp ${ }^{2}$ hybridization bonds are characterized by moderate peaks on wavenumber 3024-3028 $\mathrm{cm}^{-1}$ and the ketone group is characterized by strong and sharp peaks on wavenumber $1730-1731 \mathrm{~cm}^{-121)}$.

The results obtained are quite consistent with the structure of steroids and alkaloids. The four groups and bonds are present in the structure pf those molecules. This result points out that steroids and alkaloids are indeed found in pong-pong fruit seed extract.

\subsection{Efficacy Test}

Efficacy tests were conducted to see the effectiveness of bioinsecticides on the survival of pests to be eradicated, in this case the tobacco cutworm (Spodoptera litura). The worms are chosen in the 3rd instar phase during the larvae stage because in that phase the caterpillar is actively eating ${ }^{22}$. The selected leaves are leaves of green mustard because the worms eat all kinds of plants and the green mustard is one of the plants that is affected by the attack of the armyworm. The efficacy test was carried out using pong-pong fruit seed extract with variations in concentration and timing of sonication. The results of the efficacy test with various extract concentrations for 20 minutes sonication time are shown on Figure 2.

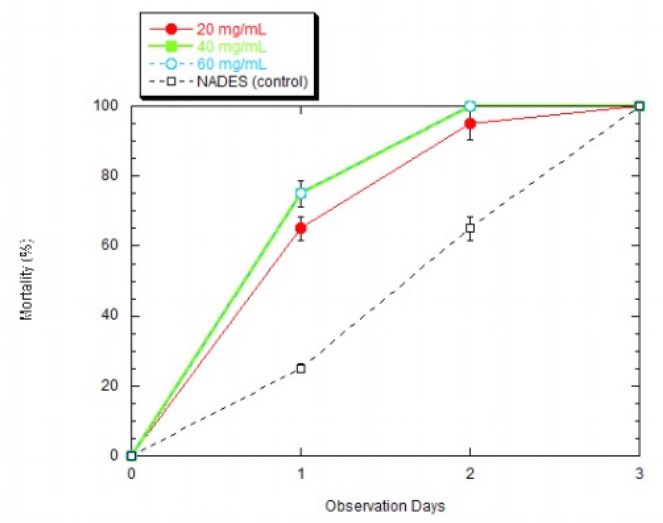

(a)

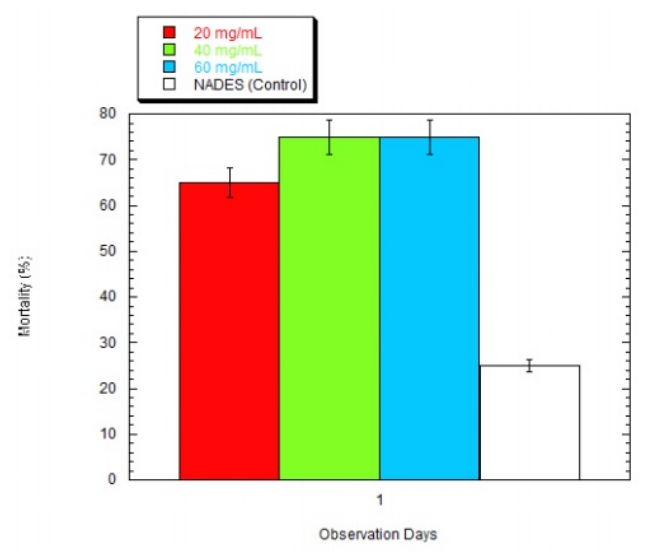

(b)

Figure 2. Efficacy Test Results for Pong-Pong Fruit Seed Extract at Sonication Time of 20 Minutes with Variety in Concentration: (a) Total Mortality Rate for 3 days; (b) Mortality Rate in the First Day 
From the results of FTIR test on pong-pong fruit seed extract obtained, all samples give out the same peak pattern, but with different percentage of transmittance. Transmittance on IR shows the ability of a group or bond to absorb IR rays. The lower the transmittance, the stronger the group or bond in absorbing the light and the higher the absorbance. Absorbance is also known to be proportional to the concentration of the species that absorbs it. So, it can be concluded that all samples have the same composition, but the concentration is different ${ }^{20)}$.

From the results obtained, the pong-pong fruit seed extracts at concentrations of $20 \mathrm{mg} / \mathrm{mL}, 40 \mathrm{mg} / \mathrm{mL}$, and $60 \mathrm{mg} / \mathrm{mL}$ are able to kill the worms. The death of the worms may be caused by the active substances found in pong-pong fruit seeds which are alkaloids and steroids. It is also found that the number of deaths of the worms increased as the observation day progressed. The higher the concentration of pong-pong fruit seed extract, the higher the mortality rate of the cutworms. However, this only applies to the concentration increase from $20 \mathrm{mg} / \mathrm{mL}$ to $40 \mathrm{mg} / \mathrm{mL}$ but does not apply to increasing concentrations from $40 \mathrm{mg} / \mathrm{mL}$ to $60 \mathrm{mg} / \mathrm{mL}$. This occurs because the amount of extracted substance has reached a maximum in concentration $40 \mathrm{mg} / \mathrm{mL}$ at the extraction time of 20 minutes. In determining the most effective concentration, the lowest concentration which can eliminate the most number of worms is selected. Thus, the concentration of pong-pong fruit seed extract that is the most effective is at a concentration of $40 \mathrm{mg} / \mathrm{mL}$, reaching $75 \%$ mortality rate in day 1 .

If the results of the efficacy test for pong-pong fruit seed extracts is compared with NADES, the mortality rate for pong-pong fruit seed extract far exceeds the NADES mortality rate. These results indicate that indeed the active ingredients act as a difference between the two solutions to kill the worms fast. However, there is an anomaly where the results of the efficacy test for NADES solvents also reach $100 \%$ on the third day. This anomaly can occur because on the second day onwards, the worms are exposed to various factors that lead to its death, including the condition of the food and test sites ${ }^{23)}$. Thus, the most representative results in this test are on the first day where the effects of these factors are said to be minimal.

Then, after getting the most effective concentration, which is at $40 \mathrm{mg} / \mathrm{mL}$, the most effective sonication time for pong-pong fruit seed extract will be sought. The following are the results of the efficacy test with variations in the sonication time and solvents for extracts with a concentration of $40 \mathrm{mg} / \mathrm{mL}$ :

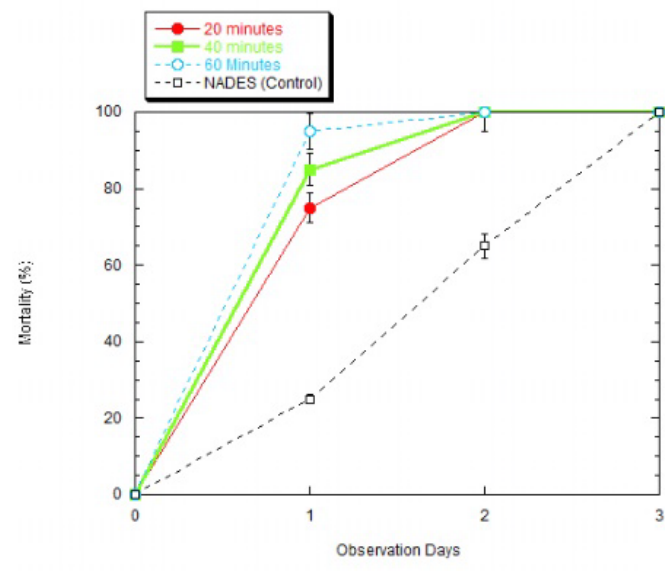

(a)

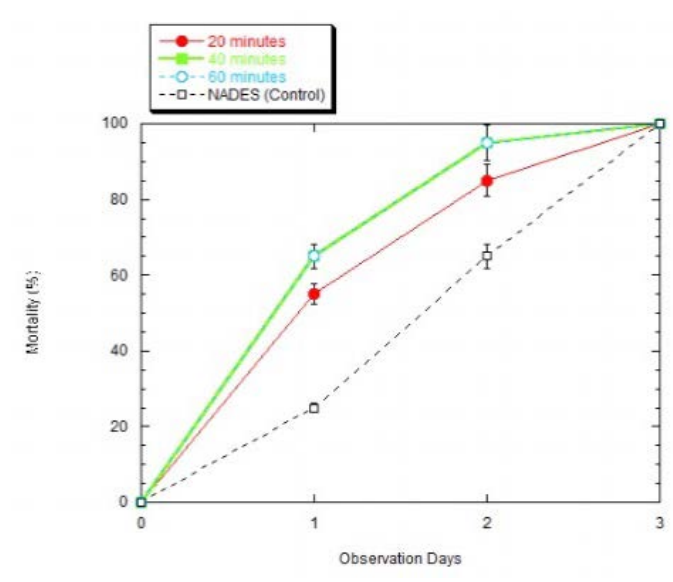

(b)

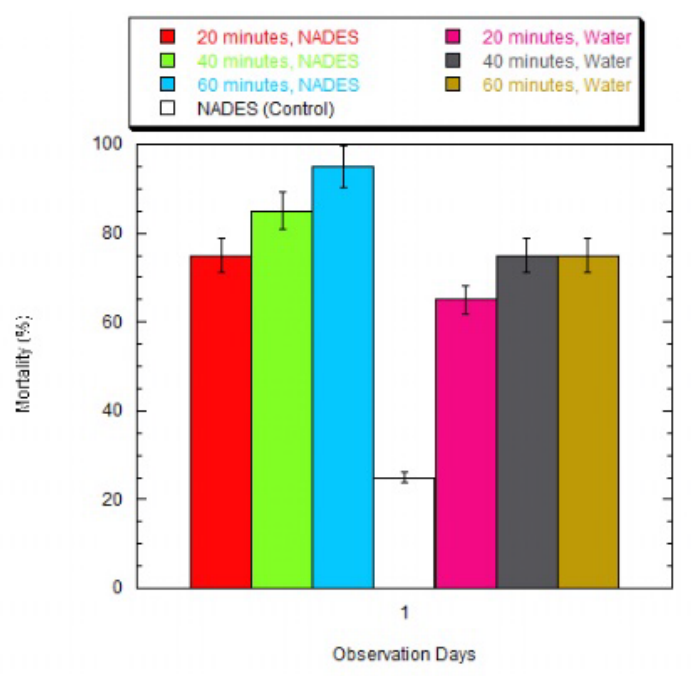

(c)

Figure 3. Efficacy Test Results for Pong-Pong Fruit Seed Extract at Concentration of $40 \mathrm{mg} / \mathrm{mL}$ with Variety in Sonication Time: (a) Total Mortality Rate of NADES Solvent for 3 Days; (b) Total Mortality Rate of Distilled Water Solvent for 3 Days; (c) Mortality Rates in the First Day 
From the results obtained, for extracts with NADES solvent and 60 minutes sonication time can be said to be the most effective, because it has a percentage of worm mortality by $95 \%$ on the first day, followed by extracts with 40 minutes sonication time of $85 \%$ and 20 minutes by $75 \%$. This result proves that longer sonication time increases the mortality rate of the worms as a result of more alkaloids and steroids are extracted with longer sonication times ${ }^{3)}$. It is also obtained that generally, the extract using NADES solvent has higher mortality rates compared using distilled water as solvents which proves the advantage of using NADES.

This bioinsecticide is more lethal compared to other methods. For example, the bioinsecticide using papaya gum as the natural substance with the same extraction method is only able to eliminate $20 \%$ of worms on the second day and $40 \%$ of worms on the third day ${ }^{14)}$. Also, extraction using the maceration method with the same natural substance is only able to eliminate $50 \%$ of worms in the first day $85 \%$ of worms in the second day ${ }^{13)}$. These numbers are inferior compared to the result of the methods used in this experiment.

\subsection{LCMS Test}

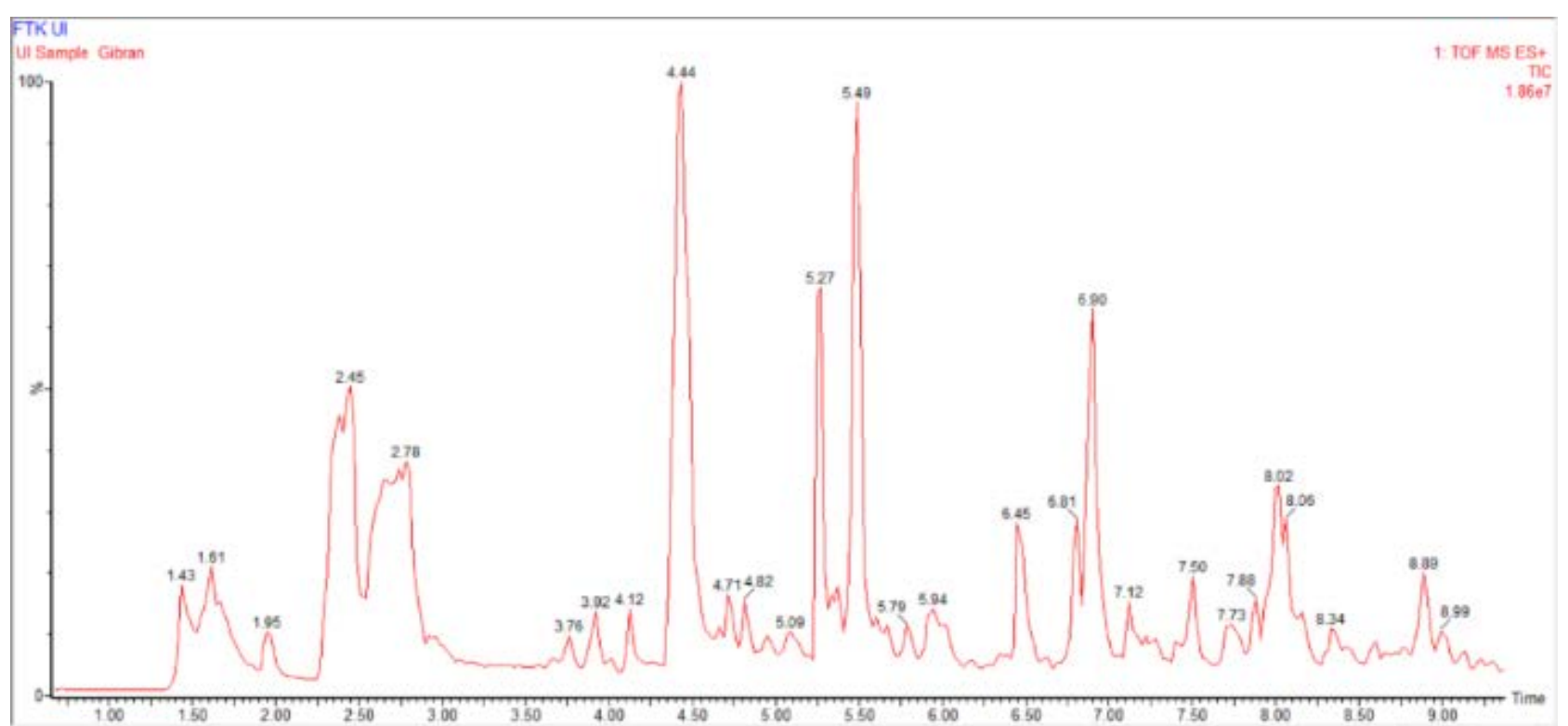

Figure 4. LCMS Test Spectrum

LCMS test is done to identify the possible substances present in the extract. The most notable substances obtained from the test is the observation of alkaloids 3[(2-Ethyl-1-piperidinyl)methyl]-1H-indole and peramine at retention times 1.61 and 2.45 minutes respectively and the observation of steroids CHEMBL2075011 and Hopantenic acid glucoside at retention times 6.45 and 8.02 minutes. These alkaloids and steroids are predicted to be the derivatives of cerberin which are the substance responsible in killing the worms by decreasing its heart rate. $^{4-5,24-27)}$

\section{Conclusion}

In this paper, pong-pong fruit seed extract is prepared to see its effectiveness in killing tobacco cutworms (Spodoptera litura) that are major pests in the agricultural industry in Indonesia. The result shows that the pong-pong fruit seed extract can kill the worms, with alkaloids and steroids being the main active substances responsible to do so. The molecule is validated using the Liebermann Test showing the presence of glycosides and FTIR tests showing the presence of several bonds and groups present in the molecule. The most effective concentration being at $40 \mathrm{mg} / \mathrm{mL}$ and the most effective sonication time is at 60 minutes as observed on the efficacy tests. Several substances in the alkaloid and steroid groups are confirmed present in the extract using the LCMS test.

\section{Acknowledgements}

The authors are grateful to the DRPM UI for financial supports under the Hibah Publikasi Internasional Terindeks untuk Tugas Akhir Mahasiswa B (PITTA B) Universitas Indonesia, Contract Number: NKB0791/UN2.R3.1/HKP.05.00/2019 
domestica), Institut Pertanian Bogor, Indonesia (2013)

5) Gaillard, Y., Krishnamoorthy, A., Bevalot, F., Cerbera odollam: a 'suicide tree' and cause of death in the state of Kerala, India, Journal of Ethnopharmacology, 95: 123-126 (2004)

6) Menezes R., Usman M., Hussain S., Madadin M., Siddiqi T., Fatima H., Ram P., Pasha S., Senthilkumaran S., Fatima T., Luis S., Cerbera odollam toxicity: A review. Journal of Forensic and Legal Medicine, 58: 113-16 (2018)

7) Dai, Y., Spronsen, J., Witkamp, G., Verpoorte, R., and Choi, Y., N Natural Deep Eutectic Solvents as New Potential Media for Green Technology. Analytica Chimica Acta. 766: 61-80 (2013)

8) Owczarek, K., Szczepanska, N., Plotka-Wasylka, J., Rutkowska, M., Shyshchak, O., Bratychak, M., Namiensik, J. Natural Deep Eutectic Solvents in Extraction Process. Journal of Chemistry \& Chemical Technology, 4: 601-606 (2016)

9) Abbott, A., Boothby, D., Capper, G., Davies, D., Rasheed, R. Deep Eutectic Solvents Formed between Choline Chloride and Carboxylic Acids: Versatile Alternatives to Ionic Liquids. Journal of American Chemical Society, 126: 9142-9147 (2004)

10) Shahriari B., Hassanpoor, A., Navehebrahim, A., Jafarinia, S., A Systematic Review of Green Human resource Management. Evergreen, 6: 177-189 (2019)

11) Kusrini, E., Supramono, D., Muhammad, I., Pranata, S., Effect of Polypropylene Plastic Waste as Cofeeding for Production of Pyrolysis Oil from Palm Empty Fruit Bunches. Evergreen, 6: 92-97

12) Pranowo, D., Bintaro (Cerbera manghas LINN) Tanaman Penghasil Minyak Nabati. Tree, 23: 91-92 (2010).

13) Dewi, M. S., Efektivitas Ekstrak Biji Bintaro (Cerbera odollam Gaertn.) Terhadap Mortalitas Ulat Grayak (Spodoptera litura (Fabricius) dan Pemanfaatannya Sebagai Poster, Universitas Jember, Indonesia (2017)

14) Tibrizi, A., Pengaruh Rasio Massa Getah Pepaya Per Volume Pelarut dan Waktu Sonikasi untuk Produksi Bioinsektisida Menggunakan Pelarut NADES dengan Gelombang Ultrasonik. Universitas Indonesia, Indonesia (2019)

15) Medina-Torres, N., Ayora-Talavera, T., EspinosaAndrews, H., Sanchez-Contreras, A., Pacheco, N., Ultrasound Assisted Extraction for the Recovery of Phenolic Compounds from Vegetable Sources. Journal of Agronomy, 47: 1-19 (2017)

16) Gul, R., Jan, S., Faridullah, S., Sherani, S., Jahan, N. (2017). Preliminary Phytochemical Screening, Quantitative Analysis of Alkaloids, and Antioxidant Activity of Crude Plant Extracts from Ephedra intermedia Indigenous to Balochistan, The Scientific World Journal, 1-7 (2017)

17) Aldred, E. Pharmacology: A Handbook for
Complementary Healthcare Professionals, Churchill Livingstone (2009)

18) Nath, M., Chakravorty, M., Chowdhury., S., Identification of Aminobenzoic Acids in Relation to Bacterial Metabolism. Nature, 157: 104-105 (1946)

19) Xiong, Q., Wilson W., Pang, J., The LiebermannBurchard Reaction: Sulfonation, Desaturation, and Rearrangment of Cholesterol in Acid, Lipids, 42: 8796 (2007)

20) Fifield, F. and, Kealey, D., Principles and Practices of Analytical Chemistry. Blackwell Science (2000)

21) Meyers, R. (2000). Encyclopedia of Analytical Chemistry, John Wiley and Sons (2000)

22) Afnan, N. T., Produksi Bioinsektisida Ulat Grayak (Spodoptera sp.) Berbasis Sistein Jahe Merah (Zingiber officinale var. rubrum), Universitas Indonesia, Indonesia (2017)

23) Indonesian Ministry of Agriculture, "Identifikasi Faktor-Faktor Yang Berpengaruh Terhadap Perkembangan Ulat Grayak Pada Tanaman Padi", (2016).

http://tanamanpangan.pertanian.go.id/index.php/ipte k/12 (Accessed 22 April 2019)

24) Schlager, S., Drager, B., Exploiting Plant Alkaloids. Current Opinion in Biotechnology, 37: 155-164 (2016)

25) Gaynor, D., Rowan, D., Isolation of Feeding Deterrents Against Argentine Stem Weevil from Ryegrass Infected with the Endophyte, Journal of Chemical Ecology, 12: 647-658 (1986)

26) Sommerville, R., Steroids. In S. Brenner \& J. H. Miller (Ed). Encyclopedia of Genetics. Elsevier (2001)

27) Arntfield, S., Proteins from Oil-producing Plants. In R. Y. Yada (Ed). Proteins in Food Processing. Woodhead Publishing (2004) 